\title{
Morbidity among nursing personnel and its association with working conditions and work organization
}

\author{
Vasconcelos $\mathrm{S}^{\mathrm{a}}$, ${ }^{*}$, Marqueze $\mathrm{E}^{\mathrm{a}}$, Gonçalves $\mathrm{L}^{\mathrm{a}}$, Lemos $\mathrm{L}^{\mathrm{a}}$, Araújo L ${ }^{\mathrm{a}}$, Fischer $\mathrm{FM}^{\mathrm{a}}$, Moreno CRC ${ }^{\mathrm{a}}$ \\ ${ }^{a}$ Environmental Health Department, School of Public Health, University of São Paulo, Dr.Arnaldo Av, 715 CEP \\ 01246-904, São Paulo,Brazil.
}

\begin{abstract}
Introduction: Work organization patterns and working conditions experienced by nursing personnel in the hospital settings may be associated to increased morbidity among these health workers. Aim: To estimate the prevalence and factors associated with self-reported diseases among nursing personnel at the emergency hospital in Rio Branco/State of Acre, Brazil. Methods: A cross-sectional study was conducted involving 272 participants who answered a questionnaire including sociodemographic characteristics, working conditions, lifestyles, work ability, and a fatigue perception scale. The selfreported diseases in the 12 months prior to data collection were considered the dependent variable. Results: A total of $85.7 \%$ of the participants reported one or more diseases in the past 12 months. Most prevalent diseases were: musculoskeletal diseases (37.1\%), digestive diseases $(28.7 \%)$, mental disorders $(28.3 \%)$, work injuries $(27.9 \%)$, and respiratory diseases $(26.8 \%)$. The following significant variables remained in the final model: high work demands (OR 2.69), reported fatigue (OR 3.59), night work (OR 6.55) and being a technician or nursing assistant (OR 4.23). Conclusions: Variables related to working conditions and work organization were associated with the occurrence of reported diseases among nursing professionals. Health promotion measures at work require a comprehensive approach including the working conditions and the work organization.
\end{abstract}

Keywords: Nursing personnel, hospital, morbidity, work conditions

\section{Introduction}

The impact of work activities on workers' health has been extensively discussed on scientific, political and socioeconomic fronts ${ }^{23}$. In addition to mediating social integration, work is a key element of physical and mental health. Work organizations submitting workers to psychosocial stressors, such as shift work, long working hours, violence at work among other unfavorable elements, may increase the risk of morbidities such as obesity, cardiovascular disease and diabetes $^{5,22,32}$.

Hospital settings typically have a significant number of nursing professionals. This group often performs activities characterized by fragmented work under rigid hierarchy and strict regulations, and usually in understaffed conditions. The interplay between these factors can contribute to the emergence of diseases, leading to higher rates of absenteeism ${ }^{3}$.
Although the high prevalence of morbidity among nursing professionals has been demonstrated by several studies ${ }^{25,24,16,11}$, few investigations have addressed the factors associated with this morbidity.

The present study aims to identify the prevalence of self-reported diseases, and its association with work-related factors among nursing personnel

\section{Methods}

\subsection{Study design}

This study adopted a cross-sectional design. Data collection included application of a questionnaire covering sociodemographic, working conditions, lifestyle and self-reported diseases and work ability.

\footnotetext{
Corresponding author. E-mail: suleimav@usp.br.
} 


\subsection{Study population}

The study population comprised nursing personnel (registered nurses, technicians and nursing assistants) in a hospital emergency service in Rio Branco/State of Acre, Brazil. The study included all workers who provided direct care to patients and who had worked at the hospital for at least six months.

Of the 298 workers eligible for the study, $8.7 \%$ refused to participate, giving a final total of $272 \mathrm{em}$ ployees. Analysis of the losses using Pearson's Chisquare test $\left(\chi^{2}\right)$ or Fisher's Exact Test, found no statistically significant differences $(p>0.05)$ between the two groups regarding sex, age, work sector or time spent at the hospital, demonstrating that these losses did not alter the characteristics of the original sample.

Among the studied workers, the majority was married $(51.4 \%)$, females $(82 \%)$; mean age was 41.7 years $(\mathrm{SD}=9.3)$. The average schooling of the respondents was 14.7 years of education $(\mathrm{SD}=1.9)$ and $70 \%$ of respondents were the main contributors to family income (breadwinners).

\subsection{Data collection}

Data on all variables included in this study were collected through questionnaire-based from October 2008 to March 2009.

\subsection{Dependent Variable}

The dependent variable was self-reported diseases. The prevalence of diseases was ascertained through a list of diseases contained in the Work Ability Index ${ }^{33}$, which also gathers data on the employee about the occurrence of diseases in the last 12 months (diagnosed by a medical doctor). These diseases were grouped according to body system affected ${ }^{33}$. To perform the multivariate analysis, logistic regression were performed. The responses were dichotomized into presence or absence of morbidity according to workers' reports.

\subsection{Independent Variables}

- Sociodemographics: Data on age, sex, family income, marital status and number of children were collected.
- Work Conditions: The workers answered to questions on several items that sought information regarding the physical environment of the workplace as well as aspects related to organization and work processes. The variables investigated were: job title, employment status, time working as a nursing professional, weekly working hours, environment features such as ambiance cleaning, lighting, ventilation, temperature, noise, maintenance of the equipment availability of materials to carry out the work activities, work demands, repetition and monotony performing the tasks, team cooperation and autonomy to make decisions.

- Perception of fatigue: Workers answered a fatigue perception questionnaire ${ }^{37}$. Scores were dichotomized and subjects classified with low fatigue ( 30 to 60 points) or high fatigue (61 to 150 points).

- Lifestyle: Participants were asked about physical activity during leisure time. The questionnaire also included questions about tobacco use and the amount of cigarettes smoked daily. Alcohol consumption was assessed based on reported alcohol consumption on weekdays and weekends.

\subsection{Data analysis}

The association of variables with self-reported diseases was tested by Pearson's Chi-square test $(\chi 2)$ or Fisher's Exact Test. Subsequently, multiple logistic regression analysis was performed for all independent variables with $\mathrm{p}<0.20$, in decreasing order of statistical significance (stepwise forward technique), and the odds ratio was estimated employing a confidence interval of $95 \%$. Sex and age were control variables. The consistency of models was checked by the Hosmer-Lemeshow test.

\subsection{Ethical issues}

The project was approved by the Ethics Committee of the Federal University of Acre and the School of Public Health, University of São Paulo.

\section{Results}

The average time working as a nursing professional was 15.9 years $(\mathrm{SD}=9.1$ years $)$ and average time 
working at the studied hospital was 11.5 years $(\mathrm{SD}=$ 8.3 years). The weekly working hours averaged 63.7 hours ( $\mathrm{SD}=13.3$ hours), ranging between 30 and 108 hours. Notably, $42.3 \%$ of individuals worked over 60 hours per week.

Regarding the prevalence of self-reported diseases, $85.7 \%$ of workers reported one or more conditions, while $24.6 \%$ reported the occurrence of five or more conditions, in the 12 months preceding the survey.

Figure 1 shows the morbidity reported by nursing personnel.

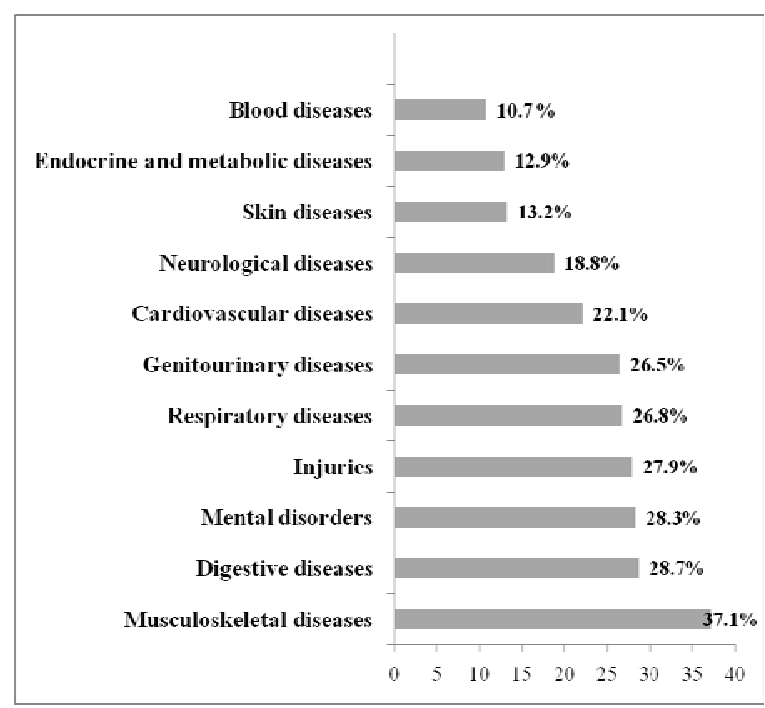

Figure1. Prevalence of self-reported diseases among nursing personnel

Regarding factors associated with prevalence of morbidity among workers, Table 1 shows the variables with $\mathrm{p}<0.20$ selected for multiple analyses.

Table 1

Bivariate logistic regression analysis of morbidity and sociodemographic variables, lifestyle and working conditions $(n=272)$.

\begin{tabular}{llll}
\hline Variables & Categories & OR & IC 95\% \\
\hline $\begin{array}{l}\text { Sociodemographics } \\
\text { Sex }\end{array}$ & $\begin{array}{l}\text { Male } \\
\text { Female }\end{array}$ & 1 & \\
& & 4.85 & $2.33 ; 10.12$ \\
Age & From 23 to 50 years & 1 & \\
& From 51 to 60 years & 3.36 & $0.99 ; 11.36$ \\
Marital status & $\begin{array}{l}\text { Single/divorced/widow } \\
\text { Married }\end{array}$ & 1 & \\
& Yes & 0.63 & $0.31 ; 1.26$ \\
$\begin{array}{l}\text { Main } \\
\text { breadwinner }\end{array}$ & No & 1 & \\
& & 1.61 & $0.79 ; 3.26$
\end{tabular}

\begin{tabular}{|c|c|c|c|}
\hline \multicolumn{4}{|c|}{ Work conditions } \\
\hline \multirow[t]{2}{*}{ Cleanliness } & Adequate & 1 & \\
\hline & Inadequate & 3.41 & $1.50 ; 7.75$ \\
\hline \multirow[t]{2}{*}{ Work demands } & Low & 1 & \\
\hline & Excessive & 2.67 & $1.32 ; 5.39$ \\
\hline \multirow[t]{3}{*}{ Shift work } & Day work & 1 & \\
\hline & Irregular work & 1.15 & $0.54 ; 2.44$ \\
\hline & Night work & 3.53 & $1.21 ; 10.32$ \\
\hline \multirow[t]{2}{*}{ Equipment } & Adequate & 1 & \\
\hline & Inadequate & 2.33 & $1.13 ; 4.79$ \\
\hline \multirow[t]{2}{*}{ Job title } & Registered Nurses & 1 & \\
\hline & $\begin{array}{l}\text { Nursing assistant / } \\
\text { technicians }\end{array}$ & 3.62 & $1.07 ; 12.22$ \\
\hline \multirow[t]{2}{*}{ Ventilation } & Adequate & 1 & \\
\hline & Inadequate & 2.04 & $1.01 ; 4.11$ \\
\hline \multirow[t]{2}{*}{ Noise Level } & Low & 1 & \\
\hline & High & 2.04 & $1.01 ; 4.11$ \\
\hline \multirow[t]{2}{*}{ Lighting } & Adequate & 1 & \\
\hline & Inadequate & 1.93 & $0.97 ; 3.85$ \\
\hline \multirow{2}{*}{$\begin{array}{l}\text { Cooperation } \\
\text { among team }\end{array}$} & Yes & 1 & \\
\hline & No & 1.85 & $0.91 ; 3.76$ \\
\hline \multirow{2}{*}{$\begin{array}{l}\text { Autonomy at } \\
\text { work }\end{array}$} & Yes & 1 & \\
\hline & No & 0.43 & $0.14 ; 1.27$ \\
\hline \multirow{2}{*}{$\begin{array}{l}\text { Availability of } \\
\text { equipment }\end{array}$} & Yes & 1 & \\
\hline & No & 1.67 & $0.83 ; 3.35$ \\
\hline \multirow[t]{2}{*}{ Work staff } & Sufficient & 1 & \\
\hline & Insufficient & 1.68 & $0.83 ; 3.43$ \\
\hline \multicolumn{4}{|l|}{ Fatigue } \\
\hline Reported & Low & 1 & \\
\hline fatigue & Excessive & 4.84 & $1.44 ; 16.27$ \\
\hline
\end{tabular}

It is worth noting that in the multiple logistic regression analysis, the variables that showed statistically significant association with the presence of morbidity were exclusively those related to working conditions (Table 2). 
Table 2

Variables associated with self-reported diseases among nursing personnel $(\mathrm{n}=272)$

\begin{tabular}{llll}
\hline Variables & Categories & OR & IC 95\% \\
\hline Shift work & Day work & 1 & \\
& $\begin{array}{l}\text { Irregular work } \\
\text { Night work }\end{array}$ & 1.74 & $0.73 ; 4.16$ \\
& & 6.55 & $1.63 ; 26.34$ \\
Reported Fatigue & Low & 1 & \\
& Excessive & 3.59 & $1.00 ; 12.88$ \\
Work demands & Low & 1 & \\
& Excessive & 2.69 & $1.21 ; 5.98$ \\
Job title & $\begin{array}{l}\text { Registered Nurse } \\
\text { Nursing assistant }\end{array}$ & 1 & \\
& technician & & \\
& & & \\
\hline
\end{tabular}

\section{Discussion}

The majority of the workers interviewed reported the presence of disease, the most frequent of which were musculoskeletal, digestive and mental disorders. Musculoskeletal diseases had the highest prevalence in the study, a finding in line with other studies $^{15,26,16}$, and were also responsible for the high number of absences from work among nursing professionals ${ }^{8}$.

It is worth noting that diseases related to the musculoskeletal system have become quite common in recent decades with significant repercussions representing a major $^{6}$ cause of morbidity and disability in adults ${ }^{30}$.

Data in the literature highlights healthcare workers as a group at risk for musculoskeletal diseases ${ }^{6}$. Nursing professionals working in the hospital settings are exposed to inadequate ergonomic factors, numerous work activities, overload and intensification of work ${ }^{5}$. These aspects can lead to mental illnesses, and contribute to the genesis of musculoskeletal disorders. Moreover, these conditions can increase the risk for work injuries and lead to high absenteeism ${ }^{20,9}$.

Concerning disorders of the digestive system, about one third of participants reported some pathology related to this system, especially ulcers and gastritis ${ }^{34}$. Such disorders may be related to the occurrence of stress from the work activities ${ }^{31}$, as well as organizational factors such as shift work ${ }^{7,18}$.

Besides the physical effects, the relationship between work and mental health of these professionals, especially registered nurses and auxiliary nursing staff, has been the focus of increasing discussion in the scientific community ${ }^{35}$.
The prevalence of mental disorders observed in the present study corroborates the results of Araújo et al. ${ }^{2}$ that found a similar prevalence $(33.3 \%)$ in a crosssectional study with 502 nursing staff members of a hospital in Bahia, specifically for minor mental disorders. Also, a study conducted by Fischer et al. ${ }^{13}$ among nursing professionals in Sao Paulo showed significant prevalence of self-reported minor mental disorders.

A study by Santos $^{28}$ of 44 nurses working in hospitals revealed that these professionals are generally stressed. Workload was identified as one of the major causes of greater physical and mental strain among these workers. The author highlighted that mental suffering of these professionals only became evident when interfered in the quality, effectiveness or efficiency of delivered care. These results are consistent with findings of the current study as far as high job demands were identified as one of the aspects that contribute to the development of morbidity. These results point to the need for health prevention and promotion of these professionals in order to prevent these workers from falling ill during work activities $^{29}$.

Regarding the factors associated with the morbidity prevalence, night workers had a six-fold greater risk of presenting morbidities compared to day workers. Shift work, particularly at night, can have negative impacts on the health and well-being of workers ${ }^{12}$. Besides the implications for family and social relationships ${ }^{9}$, night work causes serious health problems including sleep disturbances, fatigue, gastrointestinal problems ${ }^{18,10}$ cardiovascular diseases ${ }^{19,27}$ and cancer $^{36}$.

High levels of fatigue have shown a statistically significant association with morbidity. It should be noted that fatigue is a common symptom among all classes of workers, affecting not only performance and productivity but also leading to absenteeism and inability to work $^{4}$. Work-related fatigue can negatively impact the health of workers contributing to risk for hypertension, cardiovascular disease and depression $^{14}$.

The prevalence of morbidity was found to double among workers who reported high job demands. According to Magnago ${ }^{21}$, imbalance in levels of job demand and control triggers the release of stress hormones. This increase in turn can cause illness among workers.

Another variable associated with the occurrence of morbidity was job title. The results indicated higher prevalence of morbidity among nursing assistants and technicians than in registered nurses. This result 
may stem from the different characteristics and specific demands of each professional category. Aspects such as direct patient care, longer working hours, less autonomy in decision-making numbered some of the factors mentioned by the auxiliary nursing staff that might have contributed to this result $^{34}$

\section{Conclusions}

Work-related factors were found to play a major role in the occurrence of morbidities among nursing staff, pointing to the need for public health policies aimed at these workers. Health promotion measures at work should include improvements on the work environment as well as the work organization.

\section{Acknowledgments}

Brazilian research agency CAPES for supporting the Graduate Program of Public Health, School of Public Health, University of Sao Paulo and the Federal University of Acre.

\section{References}

[1] Alexandre NMC, Moraes MA, Mahayri N. Modelo de um curso de orientação sobre determinados aspectos ergonômicos e posturais no trabalho do pessoal de enfermagem. Rev Bras Enferm. 1991;19:1-5.

[2] Araújo TM, Aquino E, Menezes G, Santos CO, Aguiar L. Aspectos psicossociais do trabalho e distúrbios psíquicos entre trabalhadoras de enfermagem. Rev Saúde Pública. 2003;37:424-33.

[3] Barboza DB, Soler ZASG. Afastamento do trabalho na enfermagem: ocorrências com trabalhadores de um hospital de ensino. Rev Lat Am Enfermagem. 2003; 11:177-183.

[4] Beurskens AJHM, Bultmann U, Kant I, Vercoulen JHMM, Bleijenberg G, Swaen GMH. Fatigue among working people: validity of a questionnaire measure. Occup Environ Med. 2000;57:353-357.

[5] Black C. Working for a Healthier Tomorrow. London: The Stationary Office; 2008.

[6] Brown JG, Trinkoff A, Rempher K, McPhaul K, Brady B, Lipscomb J, et al. Nurses' Inclination to report workrelated injuries: organizational, work-group, and individual factors associated with reporting. AAOH Journal. 2005;53:213-7.

[7] Costa ES, Morita I, Martinez MAR. Percepção dos efeitos do trabalho em turnos sobre a saúde e vida social em funcionários da enfermagem em um hospital universitário do Estado de São Paulo. Cad Saúde Pública. 2000;16:553-555.

[8] Costa FM da, Vieira MA, Sena RR. Absenteísmo relacionado a doenças entre membros da equipe de enfermagem de um hospital escola. Rev Bras Enferm. 2009; 62:38-44.
[9] Costa G. The impact of shift and night work on health. Appl Ergon.1996; 27:9-16.

[10] Costa G. Factors influencing health and tolerance to shift work. Theoretical Issues in Ergonomical Science. 2003; 4:263-288.

[11] Elias MA, Navarro VL. A relação entre o trabalho, saúde e as condições de vida: negatividade e positividade no trabalho das profissionais de enfermagem de um hospital escola. Rev Lat Am Enfermagem. 2006;14:517-525.

[12] Fischer FM. As demandas da sociedade atual. In: Fischer FM, Moreno CRC, Rotenberg L. Trabalho em turnos e noturno na sociedade 24 horas. São Paulo: Editora Atheneu; 2004. p.3-17.

[13] Fischer FM, Borges FNS, Rotenberg L, Latorre MRDO, Soares NS, Rosa PLFS, Teixeira LR, Nagai R, Steluti J, Landsbergis P.Work ability of health care shift workers: what matters? Chronobiology International, 2006; 23:1165-1179.

[14]Glozier N. Mental ill health and fitness for work. Occup Environ Med. 2002;59:714-720.

[15] Gurgueira GP, Alexandre NMC, Filho HRC. Prevalência de sintomas músculo-esqueléticos em trabalhadoras de enfermagem. Rev Lat Am Enfermagem. 2003;11: 608-613.

[16] Hasselhorn H-M, Tackenberg P, Buescher A. Psychological and physical health among nurses in Europe. NEXT Scientific Report: July 2005 [internet]. Available in: http://www.next.uniwuppertal.de/EN/download.php?f=13313 $1 \mathrm{f} 960 \mathrm{ff} 1150 \mathrm{~b} 2 \mathrm{e} 0192 \mathrm{c} 51 \mathrm{~d} 18 \mathrm{f} 53$ \&target $=0$

[17] Hellerstedt WL, Jeffery RW. The association of job strain and health behaviours in men and women. International Journal of Epidemiology. 1997; 26:

[18]Knutsson A. Health disorders of shift workers. Occup. Medicine. 2003;53:103-08.

[19]Leclerc A. Shift-work and cardiovascular disease. Eur J Epidemiol. 2010; 25:285-86.

[20]Leite PC, Silva A, Merighi, MAB. A mulher trabalhadora de enfermagem e os distúrbios osteomusculares relacionados ao trabalho. Rev Esc Enferm. USP [online]. 2007;41(2):287-91.

[21] Magnano TSB de S, Lisboa MTL, Griep RH. Estresse, aspectos psicossociais do trabalho e distúrbios musculoesqueléticos em trabalhadores de enfermagem. Rev. Enfermagem. 2009;17:118-23.

[22] Mead H, Witkowski K, Gault B, Hartmann H. The influence of income, education, and work status on women's well being. Womens Health Issues 2001;11:160-72.

[23] Ministério da Saúde. Doenças relacionadas ao trabalho: manual de procedimentos para os serviços de saúde. Brasília (DF); 2001.

[24] Miranda G, Maia LMA, Lima MP, Lopes CM, Muniz PT. Nurses'Sickness at Hospital Network at Rio Branco - Acre Brazil. Online Braz J. Nurs (OBJN-ISSN 1676-4285) [online] 2005 April; 4(1) Available in: www.uff.br/nepae/objn401mirandaetal.htm

[25] Murofuse MT. Adoecimento dos trabalhadores de enfermagem da Fundação Hospitalar do Estado de Minas Gerais: reflexo das mudanças no mundo do trabalho. [tese de doutorado]. Ribeirão Preto (SP):Escola de Enfermagem /USP; 2004.

[26] Murofuse NT, Marziale MHP. Doenças do sistema osteomuscular em trabalhadores de enfermagem. Rev Lat Am Enfermagem. 2005;13:364-373.

[27] Puttonen S, Härmä M, Hublin C. Shift work and cardiovascular disease - pathways from circadian stress to morbidity. Scand J Work Environ Health. 2010;36:96-108.

[28] Santos Batista TM dos, Frazão Silva I da, Ferreira Aquino DM. Estresse ocupacional em enfermeiros de um hospital universitário. Cog Enfermagem. 2011; 16:76-81. 
[29] Santos Freitas CM dos, Tahara Sato AT. Organização do trabalho da enfermeira: Uma dimensão vinculada ao sofrimento. RevBaiana de Enfermagem. 2009; 23:113-20. Disponível em: $<$ www.scielo.br $>$.

[30] Smedley J, Trevelyan F, Inskip H, Buckle P, Cooper C, Coggon D. Impact of ergonomic intervention on back pain among nurses. Scand J Work Environ Health. 2003;29:11723.

[31] Stacciarini JMR, Tróccoli BT. O estresse na atividade ocupacional do enfermeiro. Rev Latino-am Enfermagem. 2001;9:17-25

[32] Thomas C, Hertzman C, Power C. Night work, long work hours, psychsocial work stress and cortisol secretion in mid life: evidence from a British birth cohort. 2009; 66:824-831.

[33] Tuomi K, Ilmarinen J, Jahkola A, Katajarinne L, Tulkki A. Work ability index. Helsinki, Institute of Occupational Health; 1994.

[34] Vasconcelos SP. Avaliação da capacidade para o trabalho e fadiga entre trabalhadores de enfermagem de um hospital de urgência e emergência na Amazônia Ocidental [dissertação de mestrado]. São Paulo: Faculdade de Saúde Pública da USP; 2009.

[35] Vieira Chiavegato L, Guimarães AML, Martins AD de. O estresse ocupacional em enfermeiros. In: Guimarães LAM, Grubits S, organizadores. Saúde Mental e Trabalho. São Paulo: Casa do Psicólogo; 1999. p. 169-186.

[36] World Health Organization. IARC Monographs on the evaluation of carcinogenic risks to humans. France; 2010.

[37] Yoshitake H. Relations between the symptoms and the feeling of fatigue. In: Hashimoto K. et al. Methodology in human fatigue assessment. London: Taylor \& Francis; 1975. 